\title{
Characterization of a high oleic oil extracted from papaya (Carica papaya L.) seeds
}

\author{
Caracterização de um óleo alto oleico extraído de sementes de mamão (Carica papaya L.)
}

\author{
Cassia Roberta MALACRIDA ${ }^{1 \star}$, Mieko KIMURA ${ }^{1}$ Neuza JORGE ${ }^{1}$
}

\begin{abstract}
The physicochemical characteristics, fatty acid, tocopherol, and carotenoid composition of a crude oil extracted from papaya (Carica papaya L.) seeds, formosa variety, were investigated. The oil yield from the seeds was $29.16 \%$. The data obtained for the analytical indexes were in agreement with those of other edible oils. The oil obtained had high oxidation resistance (77.97 hours). The major fatty acids in total lipid were oleic (71.30\%), palmitic (16.16\%), linoleic (6.06\%), and stearic (4.73\%) acid. The $\alpha$ and $\delta$-tocopherol were the predominant tocopherols with 51.85 and $18.89 \mathrm{mg} . \mathrm{kg}^{-1}$, respectivelly. The $\beta$-cryptoxanthin $\left(4.29 \mathrm{mg} \cdot \mathrm{kg}^{-1}\right)$ and $\beta$-carotene $\left(2.76 \mathrm{mg} . \mathrm{kg}^{-1}\right)$ were the carotenoids quantified, and the content of total phenolic compounds was $957.60 \mathrm{mg} \cdot \mathrm{kg}^{-1}$. Therefore, the potential utilization of the papaya seeds for oil production seems favorable. However, toxicological studies need to be carried out before the oil is appropriate for food applications.

Keywords: seed oil; fatty acid; tocopherol; carotenoid; total phenolics.
\end{abstract}

\section{Resumo}

As características físico-químicas e as composições de ácidos graxos, tocoferóis e carotenoides do óleo bruto extraído de sementes de mamão (Carica papaya L.), variedade formosa, foram investigadas. O rendimento em óleo das sementes foi de $29,16 \%$. Os dados obtidos para os índices analíticos comparam-se bem com os de outros óleos comestíveis. O óleo apresentou elevada resistência à oxidação (77,97 horas). Os principais ácidos graxos quantificados foram o oleico (71,30\%), seguido pelo palmítico (16,16\%), linoleico (6,06\%) e esteárico (4,73\%). O a e $\delta$-tocoferol foram os tocoferóis predominantes com 51,85 e18,9 mg.kg-1 respectivamente. A $\beta$-criptoxantina $\left(4,29 \mathrm{mg} . \mathrm{kg}^{-1}\right)$ e o $\beta$-caroteno (2,76 mg. $\left.\mathrm{kg}^{-1}\right)$ foram os carotenóides quantificados e o conteúdo de compostos fenólicos totais foi de $957,60 \mathrm{mg} \cdot \mathrm{kg}^{-1}$. Assim, a potencial utilização das sementes de mamão para a produção de óleo parece ser favorável. Entretanto, estudos toxicológicos são ainda necessários antes de o óleo ser indicado para utilização em alimentos.

Palavras-chave: óleo de sementes; ácido graxo; tocoferol; carotenóide; fenólicos totais.

\section{Introduction}

Papaya (Carica papaya L.) is native of tropical America but has now spread all over the tropical world. The fruit is usually cylindrical, large (weighing $0.5-2.0 \mathrm{~kg}$ ), and fleshy. The flesh is yellow-orange, soft, and juicy. The central cavity contains large quantities of seeds that comprise about $15 \%$ of the wet weight of the fruit (DESAI; WAGH, 1995).

The total global production of papaya averages about 10.0 million metric tons, and India and Brazil are the major producers with annual production of 3.6 and 1.9 million metric tons, respectively (FOOD..., 2008). Papaya is grown mostly for fresh consumption and papain production; however, it can be processed into jelly, jam, candy, and pickles, and its seeds are usually discarded.

Carica papaya L. seeds have been used for decades in parts of Asia and South America as a vermifugal agent (ADEBIYI; GANESAN ADAIKAN; PRASAD, 2003). In addition, papaya seed preparations have been used in folk medicine due to its abortive properties and to favor a good menstrual flow (RAO; JAMIR, 1982). Apart from these uses, since papaya seeds have a spicy flavor, they are used to adulterate black pepper (CURL; FENWICK, 1983).

Nevertheless, few studies have been conducted on the composition of papaya seeds. The composition of these seeds, compiled by Marfo, Oke and Afolabi (1986) and Puangsri, Abdulkarim and Ghazali (2005), revealed that they are a rich source of proteins (27.3-28.3\%), lipids (28.2-30.7\%), and crude fibers (19.1-22.6\%). Marfo, Oke and Afolabi (1986) found appreciable quantities of calcium and phosphorus in the seeds; however, the presence of toxicants, such as glucosinolates, was also observed.

The papaya seed oil possessed a reddish yellow color. Oleic, palmitic, linoleic, and stearic acids were the most abundant fatty acids found in the papaya seed oil (MARFO; OKE; AFOLABI, 1986; PUANGSRI; ABDULKARIM; GHAZALI, 2005). Masson et al. (2008) determined the fatty acid composition and bioactive compounds of the oil extracted from seeds of papaya, Chilean variety (Carica pubescens or Carica candamarcensis), and verified that this oil had an interesting composition (72\% of

Received 25/2/2010

Accepted 3/11/2010 (004693)

${ }^{1}$ Department of Food Engineering and Technology, São Paulo State University - UNESP, Cristóvão Colombo Street, 2265, CEP 15054-000, São José do Rio Preto, SP, Brazil, e-mail: cmalacrida@terra.com.br

${ }^{*}$ Corresponding author 
monounsaturated fatty acids with $71 \%$ of oleic acid) representing a very promising new source of a special plant oil for different applications.

Considering the global tendency with regard to the use of solid wastes and agro-industrial by products, oil extraction may add economic value to a large quantity of seeds that are generally discarded. The extraction and use of vegetable oils has for centuries played an important role in the production of a large number of industrial products and food items.

Thus, this study was conducted to determine the physicochemical characteristics and fatty acid, tocopherol, and carotenoid composition of the crude oil extracted from seeds of papaya, formosa variety, aiming to contribute to the investigations of the potential use of this seed oil in food and pharmaceutical products.

\section{Materials and methods}

\subsection{Materials}

Mature papaya fruits (Carica papaya L.), formosa variety, were purchased from the retail market of São José do Rio Preto, São Paulo, Brazil. Five batches of each fruit were obtained at different periods of harvest. The seeds were manually removed from the fruits, lightly washed with distilled water, and dried at room temperature for approximately two weeks. The seeds were then packed in black polyethylene recipients, sealed, and stored at room temperature until use.

\subsection{Methods}

\section{Proximate composition of seeds}

Moisture, lipid, and ash contents were determined following standard American... methods (1993): Ai 2-75, Ai 3-75, and Ba 5a-49, respectively. Proteins were quantified using the Kjeldahl procedure (ASSOCIATION..., 1995), and the carbohydrates and fiber contents were calculated by subtracting the sum of the percentages of moisture, lipids, protein, and ash from $100 \%$.

\section{Oil extraction}

The seed oil was obtained by extraction using petroleum ether at $40-60{ }^{\circ} \mathrm{C}$ in a Soxhlet extractor for six hours (AMERICAN..., 1993). After the extraction, the solvent was evaporated under reduced pressure at $60^{\circ} \mathrm{C}$. The oil obtained was kept in amber glass bottles, flushed with nitrogen stream, sealed, and stored in a freezer $\left(-18^{\circ} \mathrm{C}\right)$.

\section{Physicochemical characterization of seed oil}

To determine the refractive index $\left(40^{\circ} \mathrm{C}\right)$, iodine value $\left(\mathrm{g} \mathrm{I}_{2} \cdot 100 \mathrm{~g} \mathrm{~g}^{-1}\right)$, saponification value $\left(\mathrm{mg} \mathrm{KOH} . \mathrm{g}^{-1}\right)$, free fatty acids $(\%$, in oleic acid $\mathrm{w} / \mathrm{w})$, acid value ( $\left.\mathrm{mg} \mathrm{KOH} . \mathrm{g}^{-1}\right)$, and peroxide value ( $\mathrm{mEq}$ peroxide. $\mathrm{kg}^{-1}$ ) standard American... methods (1993) were followed. Unsaponifiable matter was quantified according to the method described by Hartman and Esteves (1982).

\section{Oxidative stability}

The oxidative stability index was determined using a Rancimat instrument (Metrohm Ltd., Herisau, Switzerland) following the American... method Cd 12b-92 (1993). Oxidation was carried out at $100{ }^{\circ} \mathrm{C}$ with an airflow rate of $20 \mathrm{~L} /$ hour. The oxidative stability index was defined as the time required for the oil sample to develop a measurable rancidity.

\section{Fatty acid composition}

The fatty acid composition was analyzed using gas-liquid chromatography after transesterification. The fatty acid methyl esters (FAME) were prepared according to the procedure described by Hartman and Lago (1973). The analyses of FAMEs were performed using a Varian 3900 GC gas-liquid chromatograph (Walnut Creek, USA), model equipped with a flame-ionization detector, a split-splitless injector, and an autosampler. FAMEs were separated using a CP-Sil 88 fused silica capillary column ( $50 \mathrm{~m}$ length, $0.25 \mathrm{~mm}$ internal diameter and $0.20 \mu \mathrm{m}$ film thickness). The column oven's temperature was initially held at $50{ }^{\circ} \mathrm{C}$ for 2 minutes, heated at the rate of $4{ }^{\circ} \mathrm{C}$ /minute up to $240{ }^{\circ} \mathrm{C}$, and maintained at $240{ }^{\circ} \mathrm{C}$ for 20.5 minutes. The injector and detector temperatures were kept at 230 and $250{ }^{\circ} \mathrm{C}$, respectively. Samples of $1.0 \mu \mathrm{L}$ were injected with a split ratio of 1:50. The carrier gas was hydrogen with a flow rate of $30 \mathrm{~mL} /$ minute. FAMEs were identified by comparing their retention times with those of pure FAME standards (Supelco, Bellefonte, USA) under the same operating conditions and quantified by area normalization (\%).

\section{Tocopherol profile}

The tocopherol composition of papaya seed oil was determined using high performance liquid chromatography (HPLC). Prior to the HPLC analysis, the seed oil was diluted with hexane $(0.4: 10 \mathrm{v} / \mathrm{v})$ and $20 \mu \mathrm{L}$ samples were injected. The samples were analyzed with a HPLC Varian ProStar (Walnut Creek, USA) equipped with a fluorescence detector. The operating conditions of the fluorescence detection were $\lambda$ excitation $290 \mathrm{~nm}$ and $\lambda$ emission $330 \mathrm{~nm}$. A normal phase column (Microsorb $100 \mathrm{Si}, 250 \times 4.6 \mathrm{~mm}$ internal diameter with $0.5 \mu \mathrm{m}$ particle size) was used with hexane/isopropanol (99.5:0.5 v/v) as a mobile phase. The system was operated isocratically at a flow rate of $1.2 \mathrm{~mL} /$ minute. The identification of tocopherols $(\alpha, \beta, \gamma$, and $\delta$-tocopherol) was conducted by comparing the HPLC retention time with those of standard compounds (Supelco, Bellefonte, USA) under the same operating conditions, and the quantification was based on an external standard method.

\section{Carotenoid composition}

The carotenoid composition was analyzed using high performance liquid chromatography (HPLC) after saponification of the samples. Papaya seed oil was saponified with potassium hydroxide in methanol $(20 \% \mathrm{w} / \mathrm{v})$ at room temperature for 14 hours (DE SÁ; RODRIGUEZ-AMAYA, 2003). The carotenoids were extracted with distillated water and acetone and partitioned to petroleum ether: ethyl ether 
(1:1) according to the method described by Rodriguez-Amaya (1999). The extract was dried over anhydrous sodium sulphate and the solvent was removed under a $\mathrm{N}_{2}$ stream. Immediately before injection, the residue was redissolved in $1 \mathrm{~mL}$ acetone and filtered with a $0.22 \mu \mathrm{m}$ PTFE syringe filter. The HPLC analysis was performed on a 2690 Waters separation module (Waters, Milford, USA) equipped with a quaternary pump, four channel in-line vacuum degasser, and an autosampler injector. A monomeric C18 column (Waters Spherisorb ODS2, $150 \times 4.6 \mathrm{~mm}$ internal diameter with $3.0 \mu \mathrm{m}$ particle size) was used, and the mobile phase consisted of acetonitrile: methanol: ethyl acetate containing $0.05 \%$ of triethylamine at a flow rate of $0.5 \mathrm{~mL} /$ minute. A concave gradient (curve 10) was applied from 95:0:5 to 80:10:10 at 20 minutes and to $60: 20: 20$ at 30 minutes. A UV-visible photodiode array detector was used, and the detection was at the wavelengths of maximum absorption of the carotenoids in the mobile phase $(447.6 \mathrm{~nm}$ to lutein and $454.9 \mathrm{~nm}$ to $\beta$-carotene and $\beta$-criptoxanthin). The identification of the carotenoids combined the use retention times, cochromatography with authentic samples, and absorption spectra obtained by photodiode array detector.

\section{Total phenolic content}

The content of total phenolic compounds in the methanolic extracts was determined by the Folin-Ciocalteu method (SINGLETON; ROSSI, 1965). One gram of oil was pipetted into a test tube and then $3 \mathrm{~mL}$ of methanol was added. The test tube was vortexed and then centrifuged at $3.000 \mathrm{rpm}$ for 10 minutes, and the supernatant was collected. This procedure was repeated two more times. All three extractions were combined, and the final volume was brought to $10 \mathrm{~mL}$ with the extraction solvent. An aliquot $(0.1 \mathrm{~mL})$ of methanolic extract was placed in a volumetric flash $(10 \mathrm{~mL})$ and the Folin-Ciocalteau reagent $(0.5 \mathrm{~mL})$ was added. After 3 minutes, saturated sodium carbonate $(1.5 \mathrm{~mL})$ was added. The flask was filled with water up to $10 \mathrm{~mL}$. After 2 hours of reaction at ambient temperature, absorbance at $765 \mathrm{~nm}$ against a reagent blank was measured using a UV-visible spectrophotometer (Shimadzu, Kyoto, Japan). Calibration was performed using gallic acid (SigmaAldrich, St Louis, EUA), and a calibration curve was obtained in the range of 0 to $500 \mathrm{mg} \cdot \mathrm{L}^{-1}$.

\section{Statistical analysis}

The papaya seed oil extraction experiments were repeated six times, and the oils obtained were combined. The analysis was performed based on three replicates, and the mean values and standard deviation were calculated.

\section{Results and discussion}

\subsection{Papaya seed composition}

The papaya seeds showed high concentrations of lipid (29.16\%) and protein $(25.63 \%)$. The high total lipid content found in papaya seeds may be considered economically attractive for industrial extraction, especially when compared to conventional oilseed crops such as corn and soybean which show a lipid content of 3.1-5.7 and 18-20\%, respectively (O'BRIEN, 2004). Table 1 compares the results obtained in this study to those obtained previously by Marfo, Oke and Afolabi (1986) and Puangsri, Abdulkarim and Ghazali (2005).

\subsection{Physicochemical characteristics and oxidative stability of seed oil}

The results of the physicochemical characterization and the oxidative stability of the oil extracted from papaya seeds are presented in Table 2. The refractive index (1.4581) was lower than the value reported by Marfo, Oke and Afolabi (1986). The papaya seed oil had a low iodine value $\left(79.95 \mathrm{~g} \mathrm{I}_{2} .100 \mathrm{~g}^{-1}\right)$ which confirmed it as non-drying oil. Other oils classified as non-drying are macadamia, olive, and peanut oils. Low iodine values for Carica papaya L. seed oil (66.0-74.8 g I. $\left.100 \mathrm{~g}^{-1}\right)$ were also obtained by other authors (MARFO; OKE; AFOLABI, 1986; PUANGSRI; ABDULKARIM; GHAZALI, 2005).

The saponification value $\left(196.40 \mathrm{mg} \mathrm{KOH.g^{-1 }}\right)$ and the unsaponifiable matter percentage (1.35\%) found in this study were similar to those reported for conventional vegetable oils (O'BRIEN, 2004). These values were also similar to that found in the literature regarding papaya seed oil: saponification value of $197 \mathrm{mg} . \mathrm{g}^{-1}$ (MARFO; OKE; AFOLABI, 1986) and unsaponifiable matter of 1.39\% (PUANGSRI; ABDULKARIM; GHAZALI, 2005).

The free fatty acids and the peroxide values are valuable measures of oil quality. The papaya seed oil showed $1.27 \%$ of free fatty acids, $2.53 \mathrm{mg} \mathrm{KOH} . \mathrm{g}^{-1}$ of acid value, and $5.37 \mathrm{mEq} \cdot \mathrm{kg}^{-1}$ of peroxide value. These values are not considered high since crude vegetable oil maximum contents of $5 \%$ of free fatty acids and $10 \mathrm{mEq} \cdot \mathrm{kg}^{-1}$ of peroxide value may be verified (HUI, 1996). The acidity of the oil suitable for edible purposes shall not exceed

Table 1. Proximate composition of dry papaya seeds.

\begin{tabular}{|c|c|c|c|}
\hline \multirow[t]{2}{*}{$\begin{array}{l}\text { Proximate } \\
\text { composition }\end{array}$} & \multirow[t]{2}{*}{$\begin{array}{l}\text { Determined values } \\
(\%)^{\mathrm{a}}\end{array}$} & \multicolumn{2}{|c|}{$\begin{array}{c}\text { Literature values } \\
(\%)^{\mathrm{b}}\end{array}$} \\
\hline & & 1 & 2 \\
\hline Moisture & $6.43 \pm 0.12$ & 6.2 & 7.2 \\
\hline Lipid & $29.16 \pm 0.88$ & 28.3 & 30.7 \\
\hline Protein & $25.63 \pm 0.29$ & 27.8 & 28.3 \\
\hline Ash & $8.27 \pm 0.01$ & 3.5 & 8.2 \\
\hline Carbohydrate and fiber ${ }^{c}$ & 30.51 & - & - \\
\hline
\end{tabular}

Table 2. Physicochemical characteristics of papaya seed oil.

\begin{tabular}{lc}
\hline \multicolumn{1}{c}{ Characteristics } & Values $^{\mathrm{a}}$ \\
\hline Refractive index $\left(40^{\circ} \mathrm{C}\right)$ & $1.4581 \pm 0.0001$ \\
Iodine value $\left(\mathrm{g} \mathrm{I} .100 \mathrm{~g}^{-1}\right)$ & $79.95 \pm 1.25$ \\
Saponification value $\left(\mathrm{mg} \mathrm{KOH} . \mathrm{g}^{-1}\right)$ & $96.40 \pm 1.37$ \\
Unsaponifiable matter $(\%)$ & $1.35 \pm 0.14$ \\
Free fatty acids (\%) & $1.27 \pm 0.04$ \\
Acid value (mg KOH.g & $2.53 \pm 0.08$ \\
Peroxide value (mEq.Kg & \\
Stability oxidative (hours) & $5.37 \pm 0.13$ \\
\hline
\end{tabular}

${ }^{a}$ Mean value \pm standard deviation $(n=3)$. 
$4 \mathrm{mg} \mathrm{KOH.g}{ }^{-1}$ (AMOO et al., 2004); thus the papaya oil may be suitable for consumption.

The oxidative stability index is a measurement of the resistance of lipids to oxidation. The papaya seed oil had a high oxidative stability ( 77.97 hours). This may be partially explained by the relatively low content of polyunsaturated fatty acids (Table 3 ), especially n-3 fatty acid detected in the oil. The oxidative stability of the papaya seed oil was 6.3 e 7.8 times longer than that of the soybean and sunflower oils (DEL RÉ, 2003), respectively. This suggests that crude papaya seed oil may exhibit a desired shelf life.

Few data in the literature report high oxidative stabilities at $100{ }^{\circ} \mathrm{C}$ as that obtained for the papaya seed oil. Rosales (1989) found oxidative stability values between 6.7 and 79.8 hours for olive oil samples. Arranz et al. (2008) determined the oxidative stability at $100^{\circ} \mathrm{C}$ in different nut (hazelnut, peanut, pistachio, walnut, and almond) oils and obtained the highest values to hazelnut (52.7 hours) and pistachio (44.4 hours) oils.

\subsection{Fatty acid composition of seed oil}

The fatty acid composition of papaya seed oil is shown in Table 3. The results show that the major fatty acids in the extracted oil were oleic $(71.30 \%)$, followed by palmitic $(16.16 \%)$, linoleic (6.06\%) and stearic (4.73\%) acid. Myristic, palmitoleic, margaric, linolenic, arachidic, eicosenoic, and behenic acids were found in low quantities. The values obtained are in agreement with previous works (MARFO; OKE; AFOLABI, 1986; PUANGSRI; ABDULKARIM; GHAZALI, 2005).

The fatty acid composition of the papaya seed oil showed similar content to those of olive oil that has $14 \%$ palmitic, $71 \%$ oleic and 10\% linoleic (D'IMPERIO et al., 2007). The high-oleic acid content of papaya seed oil is also similar to commercially available high-oleic vegetable oils such as canola (75\%) and safflower (77\%). These oils have sufficient stability to be used for food frying applications. In addition, the consumption of higholeic oils may have a nutritional advantage, reducing oxidative stress in vivo (CICERO et al., 2008; GARG et al., 2007).

High content of unsaturated fatty acids (UFA) was found in the analyzed oil (78.17\%), and monounsaturated fatty acids were prominent $(71.89 \%)$. Therefore, papaya seed oil has a monounsaturated fatty acid (MUFA) nutritional profile and may be a potential dietary source of MUFA. Moreover, lipids with high monounsaturated fatty acid content, such as papaya seed oil, are used in emollient skin care products, bath oils, hair conditioners, and makeup.

\subsection{Tocopherol and carotenoid compositions and total phenolic content of seed oil}

Table 4 shows the tocopherol and carotenoid compositions and total phenolic content of papaya seed oil. The oil had low content of tocopherols (74.70 mg. $\left.\mathrm{kg}^{-1}\right)$ compared with other common oils such as soybean (1797.6 mg.kg-1), maize (1618.4 mg.kg-1), and sunflower (634.4 mg.kg-1) oil (TUBEROSO et al., 2007). Usually, high amounts of tocopherols are associated with polyunsaturated fatty acid content (KAMAL-
Table 3. Fatty acid composition of papaya seed oil.

\begin{tabular}{lr}
\multicolumn{1}{c}{ Fatty acids } & Values $(\%)^{\mathrm{a}}$ \\
\hline Myristic (C14:0) & $0.20 \pm 0.02$ \\
Palmitic (C16:0) & $16.16 \pm 0.22$ \\
Palmitoleic (C16:1) & $0.27 \pm 0.01$ \\
Margaric (C17:0) & $0.13 \pm 0.01$ \\
Stearic (C18:0) & $4.73 \pm 0.08$ \\
Oleic (C18:1 n-9) & $71.30 \pm 0.12$ \\
Linoleic (C18:2 n-6) & $6.06 \pm 0.07$ \\
Linolenic (C18:3 n-3) & $0.22 \pm 0.02$ \\
Arachidic (C20:0) & $0.38 \pm 0.03$ \\
Eicosenoic (C20:1) & $0.32 \pm 0.03$ \\
Behenic (C22:0) & $0.23 \pm 0.04$ \\
UFA & 78.17 \\
MUFA & 71.89 \\
PUFA & 6.28 \\
SFA & 21.83 \\
UFA/SFA & 3.58 \\
\hline
\end{tabular}

UFA, unsaturated fatty acids; MUFA, monounsaturated fatty acids; PUFA, polyunsaturated fatty acids; SFA, saturated fatty acids. ${ }^{a}$ Mean value \pm standard deviation $(n=3)$.

Table 4. Tocopherol and carotenoid compositions and total phenolic contents of papaya seed oil.

\begin{tabular}{lc}
\hline \multicolumn{1}{c}{ Compounds } & Values $\left(\mathbf{m g . k g}^{-1}\right)^{\mathbf{a}}$ \\
\hline Total tocopherols & 74.71 \\
$\alpha$-tocopherol & $51.85 \pm 0.75$ \\
$\beta$-tocopherol & $2.11 \pm 0.15$ \\
$\gamma$-tocopherol & $1.85 \pm 0.04$ \\
$\delta$-tocopherol & $18.89 \pm 0.39$ \\
Total carotenoids & 7.05 \\
$\beta$-cryptoxanthin & $4.29 \pm 0.26$ \\
$\beta$-carotene & $2.76 \pm 0.13$ \\
Total phenolics & $957.60 \pm 24.77$ \\
\hline
\end{tabular}

a Mean values \pm standard deviation $(n=3)$; ${ }^{\text {b Total phenolics content are expressed as }}$ milligrams of gallic acid equivalent (GAE). $\mathrm{kg}^{-1}$ of oil.

ELDIN; ANDERSSON, 1997; MASSON; CAMILO; TORIJA, 2008). Hence, the low tocopherols content in the papaya seed oil may be explained by the low polyunsaturated fatty acid content, specially linoleic $(6.06 \%)$ and linolenic $(0.22 \%)$ acids.

The major tocopherols in the papaya seed oil were $\alpha$ - and $\delta$-tocopherol, which represented 69.4 and $25.3 \%$ of the total tocopherols, respectively. While $\alpha$-tocopherol is recommended for human and animal consumption because it has a high biological activity, the $\delta$-tocopherol has a higher antioxidant capacity.

The $\beta$-cryptoxanthin was the predominant carotenoid, accounting for $60.9 \%$ of the total carotenoids. This amount (4.29 mg. $\mathrm{kg}^{-1}$ ) was similar to that detected in pumpkin seed oil (4.91 mg. $\left.\mathrm{kg}^{-1}\right)$ by Parry et al. (2006). The $\beta$-carotene content $\left(2.76 \mathrm{mg} \cdot \mathrm{kg}^{-1}\right)$ was much higher than that detected in peanut, soybean, and corn oils (CABRINI et al., 2001). The $\beta$-cryptoxanthin and the $\beta$-carotene are also present in the papaya pulp (30 and $4 \%$, respectively), and lycopene was the major carotenoid (SESTANIN; RODRIGUEZ-AMAYA, 2007). 
The total phenolic content of papaya seed oil was $957.60 \mathrm{mg}$ GAE. $\mathrm{kg}^{-1}$. This value is higher than the content obtained by Siger, Nogala-Kalucka and Lampart-Szczapa (2008) in cold-pressing oilseeds from soya (1.48 mg.100 g $\left.\mathrm{g}^{-1}\right)$, sunflower $\left(1.20 \mathrm{mg} .100 \mathrm{~g}^{-1}\right)$, corn $\left(1.26 \mathrm{mg} .100 \mathrm{~g} \mathrm{~g}^{-1}\right)$, rapeseed (1.31 mg.100 g $\left.\mathrm{g}^{-1}\right)$, and rice bran (1.44 mg. $\left.100 \mathrm{~g}^{-1}\right)$.

Papaya seed oil exhibited similar behavior to that of the olive oil, which has a high level of monounsaturated fatty acids and relatively low total tocopherol levels. Furthermore, it contains substantial amounts of carotenoid pigments as well as a number of phenolic compounds (BLEKAS; TSIMIDOU; BOSKOU, 1995; KAMAL-ELDIN; ANDERSSON, 1997).

\section{Conclusions}

The study of papaya seeds revealed high oil content representing a potential source of oil rich in oleic fatty acid. The high proportion of unsaturated fatty acids would make the oil an acceptable substitute for other highly unsaturated oils. However, before being considered adequate for food applications, toxicological studies need to be carried out to ascertain whether or not this oil is safe. The physicochemical properties of the seed oil studied are in agreement with those of conventional seed oils. Papaya seed oil exhibited a very good oxidative stability without added synthetic antioxidants. Information provided by the present study is of great importance for further chemical investigations of papaya seed oil and industrial utilization of the papaya seeds as a raw material to foods and cosmetics.

\section{Acknowledgements}

The authors are grateful for the financial support provided by the foundations FAPESP - São Paulo State Foundation for Support of Science, CAPES - Brazilian research supporting foundation, and $\mathrm{CNPq}$ - The National Council for Scientific and Technological Development.

\section{References}

ADEBIYI, A.; GANESAN ADAIKAN, P.; PRASAD, R. N. V. Tocolytic and toxic activity of papaya seed extract on isolated rat uterus. Life Science, v. 74, n. 5, p. 581-592. 2003. PMid:14623029. http://dx.doi. org/10.1016/j.lfs.2003.06.035

AMERICAN OIL CHEMISTS' SOCIETY - AOCS. Official Methods and Recommended Practices of the American Oil Chemists' Society. Champaing: AOCS, 1993.

AMOO, I. A. et al. Characteristics of oil extract from gourd (Cucurbita maxima) seed. Journal of Food, Agriculture and Environment, v. 2, n. 2, p. 38-39, 2004.

ARRANZ, S. et al. Comparison between free radical scavenging capacity and oxidative stability of nut oils. Food Chemistry, v. 110, n. 4, p. 985-990, 2008. http://dx.doi.org/10.1016/j.foodchem.2008.03.021

ASSOCIATION OF OFFICIAL ANALYTICAL CHEMISTS - AOAC. Official methods of analysis of the Association of Official Analytical Chemists. Arlington: AOAC, 1995.

BLEKAS, G.; TSIMIDOU, M.; BOSKOU, D. Contribution of a-tocopherol to olive oil stability. Food Chemistry, v. 52, n. 3, p. 298-294, 1995.
CABRINI, L. et al. Antioxidants and total peroxyl radical-trapping ability of olive and seed oils. Journal of Agricultural and Food Chemistry, v. 49, n. 12, p. 6026-6032, 2001. PMid:11743803. http:// dx.doi.org/10.1021/jf010837t

CICERO, A. F. G. et al. Changes in LDL fatty acid composition as a response to olive oil treatment are inversely related to lipid oxidative damage: the EUROLIVE study. Journal of the American College of Nutrition, v. 27, n. 2, p. 314-320, 2008.

CURL, C. L.; FENWICK, G. R. On the determination of papaya seed adulteration of black pepper. Food Chemistry, v. 12, n., p. 241247, 1983.

DEL RÉ, P.V. Comportamento de óleos vegetais em frituras descontínuas de produtos pré-fritos congelados. 2003. $121 \mathrm{f}$. Dissertação (Mestrado em Engenharia e Ciência de Alimentos)Instituto de Biociências, Letras e Ciências Exatas, Universidade Estadual Paulista, São José do Rio Preto, 2003.

DESAI, U. T.; WAGH, A. N. Papaya. In: SALUNKHE, D. K.; KADAM, S. S. (Ed.). Handbook of fruit science and technology: production, composition, storage and processing. New York: Marcel Dekker, 1995. p. 297-313.

DE SÁ, M. C.; RODRIGUEZ-AMAYA, D. B. Carotenoid composition of cooked green vegetables from restaurants. Food Chemistry, v. 83, n. 4, p. 595-600, 2003.

D'IMPERIO, M. et al. Statistical analysis on Sicilian olive oils. Food Chemistry, v. 102, n. 3, p. 956-965, 2007. http://dx.doi.org/10.1016/j. foodchem.2006.03.003

FOOD AND AGRICULTURE ORGANIZATION OF THE UNITED NATIONS - FAO. FAOSTAT Agriculture. FAO, 2008. Disponível em: http://faostat.fao.org/site/567/default.aspx. Acesso em: 10 mar. 2010.

GARG, M. L. et al. Macadamia nut consumption modulates favorably risk factors for coronary artery disease in hypercholesterolemic subjects. Lipids, v. 42, n. 6, p. 583-587, 2007. PMid:17437143. http:// dx.doi.org/10.1007/s11745-007-3042-8

HARTMAN, L.; ESTEVES, W. Tecnologia de óleos e gorduras vegetais. São Paulo: Secretaria de Estado da Indústria, 1982.

HARTMAN, L.; LAGO, R. C. A. Rapid preparation of fatty acid methyl esters from lipids. Laboratory Practice, v. 22, p. 475-476, 1973.

HUI, Y. H. Bailey's industrial oil \& fat products. New York: John Wiley \& Sons, 1996.

KAMAL-ELDIN, A.; ANDERSSON, R. A multivariate study of the correlation between tocopherol content and fatty acid composition in vegetable oils. Journal of the American Oil Chemists' Society, v. 74, n. 4, p. 375-380, 1997.

MARFO, E. K.; OKE, O. L.; AFOLABI, O. A. Chemical composition of papaya (Carica papaya) seeds. Food Chemistry, v. 22, n. 4, p. 259-266, 1986. http://dx.doi.org/10.1016/0308-8146(86)90084-1

MASSON, L.; CAMILO, C.; TORIJA, M. E. Caracterización del aceite de coquito de palma chilena (Jubaea chilensis). Grasas y Aceites, v. 59, n. 1, p.33-38, 2008.

MASSON, L. et al. New sources of oilseeds from Latin American native fruits. Natural Product Communications, v. 3, n. 3, p.357-362, 2008.

O'BRIEN, R. D. Fats and oils: formulating and processing for applications. Boca Raton: CRC Press, 2004.

PARRY, J. et al. Characterization of cold-pressed onion, parsley, cardamom, mullein, roasted pumpkin, and milk thistle seed oils. Journal of the American Oil Chemists' Society, v. 83, n. 10, p. 847-854, 2006.

PUANGSRI, T.; ABDULKARIM, S. M.; GHAZALI, H. M. Properties of Carica papaya L. (papaya) seed oil following extractions using solvent and aqueous enzymatic methods. Journal of Food Lipids, v. 12, n. 1, p. 62-76, 2005. http://dx.doi.org/10.1111/j.1745-4522.2005.00006.x 
RAO, R. R.; JAMIR, N. S. Ethnobotanical studies in Nagaland. I. Medicinal plants. Economic Botany, v. 36, n. 2, p. 176-181, 1982. http://dx.doi.org/10.1007/BF02858714

RODRIGUEZ-AMAYA, D. B. A guide to carotenoids analisis in food. Washington: ILSI Press, 1999.

ROSALES, G. Determinación de la estabilidad oxidativa de aceite de oliva vírgenes: comparación entre el método del oxígeno activo (A.O.M.) y el método Rancimat. Grasas y Aceites, v. 40, n.1, p.1-5, 1989.

SESTANIN, M. A.; RODRIGUEZ AMAYA, D. B. Carotenoid levels in papaya and peach determined by high performance liquid chromatography. Ciência e Tecnologia de Alimentos, v. 27, n. 1, p. 13-19, 2007.
SIGER, A.; NOGALA-KALUCKA, M.; LAMPART-SZCZAPA, E. The content and antioxidant activity of phenolic compounds in cold-pressed plant oils. Journal of Food Lipids, v. 15, n. 2, p. 137149, 2008. http://dx.doi.org/10.1111/j.1745-4522.2007.00107.x

SINGLETON, V. L.; ROSSI, J. A. Colorimetry of total phenolics with phosphomolybdic and phosphotungstic acid reagents. American Journal of Enology and Viticulture, v. 16, n. 3, p. 144-158, 1965.

TUBEROSO, C. I. G. et al. Determination of antioxidant compounds and antioxidant activity in commercial oilseeds for food use. Food Chemistry, v. 103, n. 4, p. 1494-1501, 2007. http://dx.doi. org/10.1016/j.foodchem.2006.08.014 